\title{
Radiation Oncology Device Approval in the United States and Canada
}

\author{
Craig A. Beers ${ }^{1}$, Wendy L. Smith ${ }^{2}$, Sarah Weppler ${ }^{2}$, Colleen Schinkel ${ }^{2}$, Harvey Quon ${ }^{3}$ \\ 1. Radiation Oncology, Cumming School of Medicine, University of Calgary, Calgary, CAN 2. Medical \\ Physics, University of Calgary, Calgary, CAN 3. Radiation Oncology, Tom Baker Cancer Centre, Calgary, CAN
}

$\square$ Corresponding author: Craig A. Beers, cabeers@ucalgary.ca

Disclosures can be found in Additional Information at the end of the article

\section{Abstract}

\section{Background}

Medical devices are a crucial component in the field of radiation oncology. The review and licensing of radiation oncology devices (RODs) is managed on a national basis in Canada by Health Canada and in the United States by the Food and Drug Administration (FDA). The purpose of this study was to examine differences in ROD licensing timelines between Health Canada and the FDA that may impact the ability of Canadians to access the most up-to-date radiation oncology care.

\section{Methods}

A list of ROD was compiled by searching keywords, manufacturers, and proprietary device names in the publicly accessible Canadian Medical Devices Active Licence Listing (MDALL) and the American Establishment Registration \& Device Listing and the 510(k) Premarket Notification database. ROD licensing dates were then obtained through both databases. ROD were included if they were licensed in both countries.

\section{Results}

A total of 51 RODs were included in this study and it was found that $71 \%(36 / 51)$ were issued licenses for sale in the United States before Canada, at a mean of 506 days sooner (median [IQR] = 282 [326.5]). No trends in licensing dates were found by stratifying devices by type. Analyses were limited to the date of licensing only, as Health Canada provided no publicly-available information regarding submission milestones such as first submission date for the RODs studied.

\section{Conclusions}

Received 11/18/2018

Review began $11 / 27 / 2018$ Review ended 03/20/2019 Published 04/01/2019

\section{(c) Copyright 2019}

Beers et al. This is an open access article distributed under the terms of the Creative Commons Attribution License CC-BY 3.0., which permits unrestricted use, distribution, and reproduction in any medium, provided the original author and source are credited.
The majority of radiation oncology devices examined were licensed for sale in the USA before Canada. Due to the absence of publicly available information regarding initial ROD application date, we cannot evaluate the impact of the approval process on the overall difference in licensing date. Importantly, this research highlights a lack of publicly-available information from Health Canada regarding the medical device approval process for the radiation oncology devices studied herein.

Categories: Radiation Oncology, Healthcare Technology

Keywords: radiation oncology, medical device, health canada, fda

\section{Introduction}

Radiation oncology is a field dependent on the availability of the medical devices, including linear 
accelerators, brachytherapy technologies, patient imaging and monitoring devices, quality assurance (QA) tools, and treatment planning software [1]. With the rapid evolution of radiation oncology devices (RODs) and technology, there is a constant desire by both patients and health care providers to have the most up-to-date technology in use at Canada's cancer centers [1].

The introduction of a medical device to the Canadian market is a complicated process that is regulated by the Medical Devices Regulations of the Food and Drugs Act and overseen by the Therapeutic Products Directorate through the Medical Device Bureau, both contained within Health Canada [2]. Specifically, the Medical Devices Bureau reviews applications for new medical device licenses and contributes to the policy and development of new medical device regulations [3]. Many radiation oncology devices are additionally regulated in accordance with the Class II Nuclear Facilities and Prescribed Equipment Regulations under the Nuclear Safety and Control Act (NSCA) by the Canadian Nuclear Safety Commission (CNSC) [4].

The United States of America has similar provisions; medical device approvals and regulations are mainly covered by the Federal Food, Drug, and Cosmetic Act (FDCA), while the Center for Devices and Radiological Health (CDRH) of the Food and Drug Administration (FDA) is responsible for regulating medical devices in the US market [5]. RODs, in particular, are governed through the Radiation Control provisions of the Radiation Control for Health and Safety Act of 1968 [6] and the United States Food and Drug Administration's Center for Devices and Radiological Health $(\mathrm{CDRH})$ is responsible for regulating radiation-emitting electronic products [7].

A recent comparison of oncology drug approval time between Health Canada and the FDA found that on average, the time from submission to Health Canada to approval for oncology drugs is three months longer than the same process at the FDA [8]. Similarly, a comparison of all novel therapeutic agents submitted to Health Canada, the FDA, and the European Medicines Agency (EMA) found that on average the FDA reviewed applications for novel therapeutics 44 to 71 days more quickly than Health Canada or the EMA [9]. The authors also found that among drugs approved in the United States and Canada, 86\% were first approved in the United States, and the drugs available a median of 355 days earlier in the United States.

A review of current literature identified no published research similarly comparing approval times for RODs in the USA and Canada. The objective of the project was therefore to compare licensing dates for RODs that are approved for sale in both Canada and the USA.

\section{Materials And Methods}

We used only publicly accessible information and data to ensure transparency and reproducibility of our findings. To generate a list of RODs that are currently licensed for sale in Canada, a thorough search of Health Canada's Medical Devices Active Licence Listing, MDALL (https://health-products.canada.ca/mdall-limh/index-eng.jsp), was performed. Search criteria included but were not limited to: keyword searches (Radiation, Linear Accelerator, LINAC, Brachytherapy, Proton, Gamma), company names (Accuray, Brainlab, Elekta Limited, Philips, Theragenics Corporation, Siemens, Varian Medical Systems, Xoft Inc.), and proprietary device names (Novalis, AlignRT, CyberKnife, Aria, MRIDIAN, TrueBeam). Additionally, vendor and exhibitor lists from the American Association of Physicists in Medicine 2017 Annual Scientific Meeting were used to generate additional MDALL search terms including additional ROD manufacturers (Augmentix, Best Medical Canada, C-Rad Positioning, IRT Systems, IsoAid, Mevion Medical Systems, MIM Software Inc., Mobius Medical Systems, Oncology Systems Limited, Raysearch Laboratories, Scandidos, Sensus Healthcare, Sun Nuclear Corporation, Viewray Incorporated, Vision RT Limited). For each entry, the license device first issue date was abstracted for further analyses. Our search was limited to devices issued licenses between January 1, 2000 and July 2, 2018, in order to capture only contemporary devices currently in use.

Once a list of devices licensed for sale in Canada was generated, each device was searched for in 
the following United States FDA databases: Establishment Registration \& Device Listing (https:/www.accessdata.fda.gov/scripts/cdrh/cfdocs/cfRL/rl.cfm) and 510(k) Premarket Notification (https://www.accessdata.fda.gov/scripts/cdrh/cfdocs/cfPMN/pmn.cfm). In order to be included in the study dataset, exact matches were required for device name, version, and applicant/company of manufacture. Any device not matching all three criteria were excluded from the dataset. As with the Canadian database, the license device first issue date for each entry was collected.

Once the database was populated with precisely matched devices found in both American and Canadian databases, entries were stratified into the following categories: general accessories (e.g., patient positioning system, shielding device, etc.), brachytherapy technology, imaging and monitoring accessory, linear accelerator, proton accelerator, quality assurance device (QA), superficial radiotherapy device, and treatment planning/record \& verify software. Data were then analyzed to determine differences in licensing dates between the United States and Canada. Date difference data were assessed qualitatively for observable trends between the country of licensing and device category.

\section{Results}

A total of 51 devices matched the inclusion criteria for this study (Supplementary Table 1, see Appendix) and were subcategorized as follows: two general accessories, six brachytherapy technology devices, four imaging and monitoring accessories, 13 linear accelerators, one proton accelerator, seven QA devices, one superficial radiotherapy device, and 17 treatment planning/record \& verify software packages. Data from the linear accelerator category can be seen in Table 1. Seventy-four (74) devices were excluded due to a lack of exact match of device name, version, company, or due to being licensed for sale in one country or not the other. A listing of excluded devices can be found in Supplementary Table 2 (see Appendix). 


\section{Cureus}

\begin{tabular}{|c|c|c|c|c|c|}
\hline Device name & Company & $\begin{array}{l}\text { CAN } \\
\text { issue } \\
\text { date }\end{array}$ & $\begin{array}{l}\text { USA } \\
\text { issue } \\
\text { date }\end{array}$ & $\begin{array}{l}\text { Difference in days } \\
\text { (USA before CAN) }\end{array}$ & $\begin{array}{l}\text { Difference in days } \\
\text { (CAN before USA) }\end{array}$ \\
\hline Mridian Linac System & $\begin{array}{l}\text { Viewray } \\
\text { Incorporated }\end{array}$ & $\begin{array}{l}2-\text { Aug- } \\
17\end{array}$ & $\begin{array}{l}24-F e b- \\
17\end{array}$ & 159 & \\
\hline $\begin{array}{l}\text { Oncor Expression Digital Linear } \\
\text { Accelerator }\end{array}$ & Siemens & $\begin{array}{l}\text { 28-Aug- } \\
06\end{array}$ & $\begin{array}{l}\text { 15-Mar- } \\
06\end{array}$ & 166 & \\
\hline Artiste Mv - Linear Accelerator & Siemens & $\begin{array}{l}\text { 12-Aug- } \\
08\end{array}$ & $\begin{array}{l}27-\text { Dec- } \\
07\end{array}$ & 229 & \\
\hline Halcyon Medical Linear Accelerator & $\begin{array}{l}\text { Varian } \\
\text { Medical } \\
\text { Systems, Inc }\end{array}$ & 6-Jul-18 & $\begin{array}{l}27-J u n- \\
17\end{array}$ & 374 & \\
\hline Tomotherapy Treatment System Tomohd & Accuray & $\begin{array}{l}27-\text { Nov- } \\
13\end{array}$ & $\begin{array}{l}\text { 29-Aug- } \\
12\end{array}$ & 455 & \\
\hline Radixact Treatment Delivery System & Accuray & $\begin{array}{l}2-\text { Oct- } \\
17\end{array}$ & $\begin{array}{l}\text { 24-Jun- } \\
16\end{array}$ & 465 & \\
\hline Novalis (Shaped Beam Surgery System) & Brainlab Ag & $\begin{array}{l}\text { 2-Dec- } \\
03\end{array}$ & $\begin{array}{l}\text { 3-Nov- } \\
00\end{array}$ & 1124 & \\
\hline $\begin{array}{l}\text { Cyberknife Robotic Radiosurgery System } \\
\text { - } 1000 \text { Mu/Minute Linear Accelerator }\end{array}$ & Accuray & $\begin{array}{l}\text { 16-Aug- } \\
06\end{array}$ & $\begin{array}{l}30-\text { Oct- } \\
06\end{array}$ & & 75 \\
\hline $\begin{array}{l}\text { Brainscan Stereotactic Radiosurgery } \\
\text { System }\end{array}$ & Brainlab Ag & $\begin{array}{l}\text { 8-Feb- } \\
00\end{array}$ & $\begin{array}{l}\text { 13-Jul- } \\
00\end{array}$ & & 156 \\
\hline Leksell Gamma Knife Perfexion & $\begin{array}{l}\text { Elekta } \\
\text { Instrument Ab }\end{array}$ & $\begin{array}{l}30 \text {-Aug- } \\
06\end{array}$ & $\begin{array}{l}\text { 5-Mar- } \\
07\end{array}$ & & 187 \\
\hline Truebeam & $\begin{array}{l}\text { Varian } \\
\text { Medical } \\
\text { Systems, Inc }\end{array}$ & $\begin{array}{l}2-D e c- \\
10\end{array}$ & $\begin{array}{l}\text { 18-Aug- } \\
11\end{array}$ & & 259 \\
\hline Cyberknife M6 Series System & Accuray & $\begin{array}{l}23-\text { Oct- } \\
13\end{array}$ & $\begin{array}{l}7-J a n- \\
15\end{array}$ & & 441 \\
\hline $\begin{array}{l}\text { Cyberknife Vsi Robotic Radiosurgery } \\
\text { System }\end{array}$ & Accuray & $\begin{array}{l}\text { 18-Mar- } \\
11\end{array}$ & $\begin{array}{l}26-\text { Oct- } \\
12\end{array}$ & & 588 \\
\hline
\end{tabular}

TABLE 1: Licensure Information in Canada and the USA for Linear Accelerators from 2000 to Present

In total, 36 (71\%) of the 51 devices were licensed for sale in the USA before Canada (Figure 1). Devices were licensed in the USA a mean of 506 days before Canada (median [interquartile range]: 283 [327 days]). Of the 15 devices licensed for sale in Canada before the USA, the mean difference was 571 days (median [interquartile range]: 187 [369 days]). These data can be found in Table 2. 


\section{Cureus}

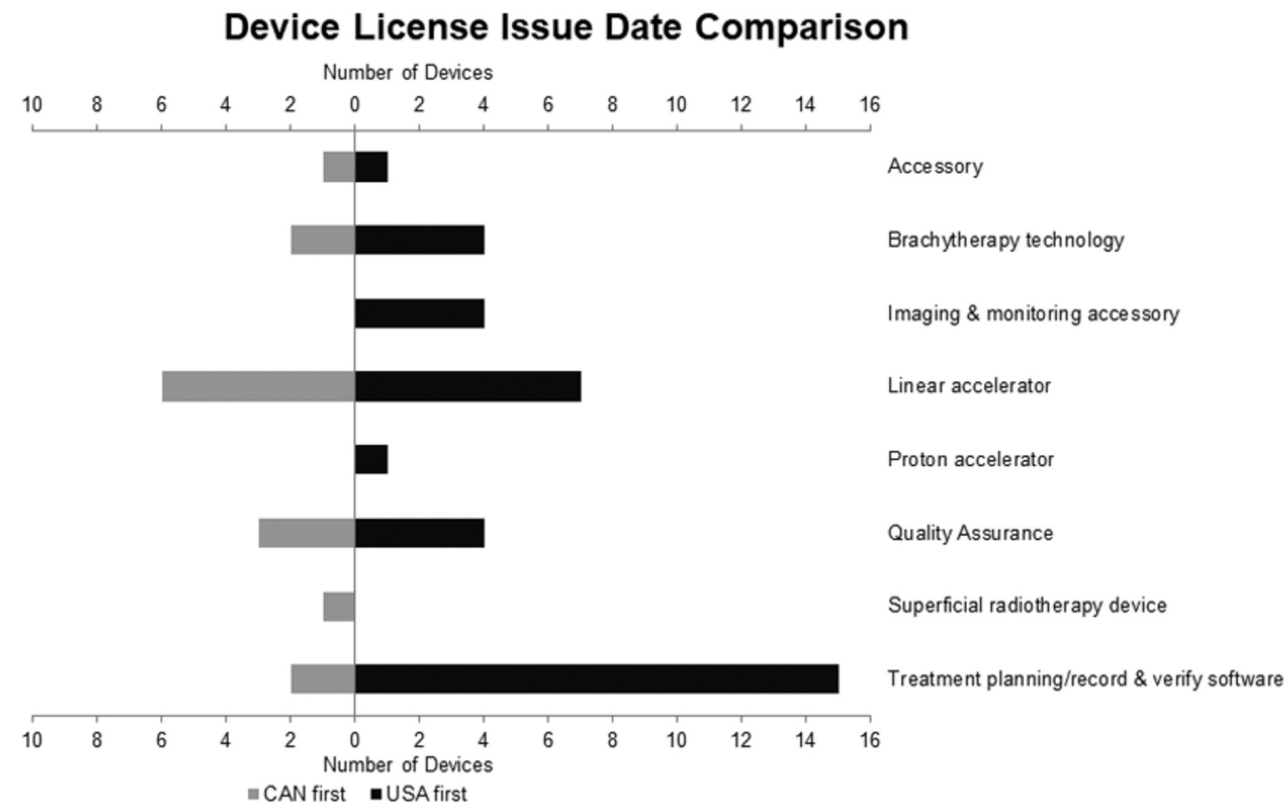

FIGURE 1: Comparison of Device Licensure Date Between Canada and the USA

Total number of devices examined

Number of devices licensed for sale in the USA before Canada

Number of devices licensed for sale in Canada before the USA

Devices licensed in the USA before Canada (36/51)

Mean difference [St.Dev] in licensing date (days)

Median $[\mathrm{IQR}]$ difference in licensing date (days)

Devices licensed in Canada before the USA (15/51)

Mean difference in [St.Dev] licensing date (days)

Median $[\mathrm{IQR}]$ difference in licensing date (days)

\section{1}

36

15

$506[639.4]$

$282[326.5]$

$572[1168.1]$

$187[369.0]$

\section{TABLE 2: Radiation Device Licensure in Canada and the USA (January 2000 - July} 2018)

The results for each category are summarized in Table 3. Of the eight device categories examined, the majority of devices were listed for sale in the USA first in seven categories (88\%). The minimum difference in days was found to be 94 , while the maximum was 3470 days. The one ROD category where the majority were licensed in Canada first was a superficial radiotherapy device. The single device was licensed in Canada 194 days prior to the USA. Additionally, the devices examined had 24 unique manufacturers. Stratifying these data by the company of manufacture failed to reveal any trend towards favoring licensure in Canada or the United States first; however, 


\section{Cureus}

it is difficult to draw conclusions from these results as $17 / 24$ (71\%) of the examined manufacturers had two devices or fewer included in this dataset.

\begin{tabular}{|c|c|c|c|c|c|}
\hline Category & $\begin{array}{l}\text { Total } \\
\text { devices }\end{array}$ & $\begin{array}{l}\text { Number licensed } \\
\text { in USA first }\end{array}$ & $\begin{array}{l}\text { Median days } \\
\text { difference (IQR) }\end{array}$ & $\begin{array}{l}\text { Number licensed in } \\
\text { Canada first }\end{array}$ & $\begin{array}{l}\text { Median days } \\
\text { difference (IQR) }\end{array}$ \\
\hline Accessory & 2 & 1 & 244 (n/a) & 1 & $871(\mathrm{n} / \mathrm{a})$ \\
\hline Brachytherapy technology & 6 & 4 & 273 (197) & 2 & $156(17)$ \\
\hline $\begin{array}{l}\text { Imaging \& Monitoring } \\
\text { Accessory }\end{array}$ & 4 & 4 & $1124(477)$ & 0 & $\mathrm{n} / \mathrm{a}$ \\
\hline Linear Accelerator & 13 & 7 & $374(214)$ & 6 & $187(209)$ \\
\hline Proton Accelerator & 1 & 1 & $949(0)$ & $\mathrm{n} / \mathrm{a}$ & $\mathrm{n} / \mathrm{a}$ \\
\hline Quality Assurance & 7 & 4 & $229(198)$ & 3 & $158(117)$ \\
\hline Superficial RT & 1 & 0 & $n / a$ & 1 & 194 (n/a) \\
\hline $\begin{array}{l}\text { Treatment Planning/Record } \\
\text { \& Verify Software }\end{array}$ & 17 & 15 & $283(290)$ & 2 & $2477(380)$ \\
\hline
\end{tabular}

\section{TABLE 3: License Date Comparison by Category}

\section{Discussion}

Our analysis of licensing date for radiation oncology devices in the United States and Canada from 2000 to 2018 reveals that $71 \%$ (36/51) of the devices licensed for sale over that timeframe was licensed in the United States before Canada, a mean of 506 days (1.4 years) earlier. Given that Canada has 43 cancer centers, while the United States has approximately 1500 cancer centers, it is not surprising that companies may choose to go to market in the USA first [10]. From a financial standpoint, the medical device market in the United States is much larger than the Canadian market: SelectUSA, a government program led by the U.S. Department of Commerce, estimates that the United States represents the largest medical device market in the world at US\$156 billion (40\% of the global medical device market) in 2017 [11], while estimates from the Government of Canada put the Canadian market at US $\$ 6.7$ billion (6\% of the global medical device market) in 2016 [12]. Additionally, we found that 13 out of the 24 companies (54\%) included in this study were founded, or had their worldwide headquarters within the USA. This may represent another explanatory variable for our results. No specific trends in licensing date and time were identified by stratifying the devices by category (Table 3).

Licensing fees do not appear to be an explanatory variable for why the majority of RODs are licensed for sale in the United States before Canada. Indeed, medical device costs appear to be much lower for entering the Canadian market: submitting a device for a Medical Device Establishment Licence through Health Canada costs \$8,272 CAD [13], applying for the Medical Device Licence Application Review for a Class III device (the majority RODs studied here were Class III) costs \$9,881 CAD [14], and the annual Right to Sell Licensed Class II, III, or IV Medical Devices $\$ 383$ CAD [15]. Fees for the FDA are dependent on whether or not a predicate device has already been approved: If a substantially equivalent predicate legally marketed device exists, a new application through the $510(\mathrm{k})$ process will cost \$10,566 USD $(\$ 2,642$ USD if the applicant is a Small Business) [16]. If no predicate device is found, a Premarket Approval review will be required 
at a cost of $\$ 310,764$ USD (Small business $\$ 77,691$ USD) [16]. Additionally, there is an Annual Establishment Registration Fee of \$4,624 USD [16]. Based on these values, Canadian medical device licensing fees do not appear to be a barrier for bringing RODs to market in Canada.

Unfortunately, without information regarding the initial ROD licensing application date, we are unable to draw any conclusion about whether differences in licensing dates are due to manufacturers applying earlier in one country, or if the delay is in the approvals process itself.

An important issue that we feel should be addressed, is a lack of publicly-available information by Health Canada in the area of medical device licensing. The intended goal of this project was to examine the length of time required for the approval of a medical device in Canada and the United States, from initial submission date to final approval. As previously discussed, this topic has been explored for novel therapeutic agents [9] and specifically for oncology drugs [8]. Unfortunately, the Medical Devices Active Licence Listing (MDALL) database maintained by Health Canada does not publicly provide date of license submission. In comparison, both submission and approval dates are publicly available through the United States FDA databases, the Establishment Registration and Device Listing and 510(k) Premarket Notification database. A comparison of the Canadian and American database output can be seen in Table 4. According to Health Canada's website, Summary Basis of Decision (SBD) documents are generated for drugs and medical devices for sale in Canada and document regulatory, safety, effectiveness and quality (chemistry and manufacturing) considerations. SBD provide a detailed timeline of submission milestones including submission filing date, completion dates for multiple quality control evaluations, and the Notice of Compliance (NOC) issue date (the NOC is issued following the satisfactory review of a submission for a new drug, and signifies compliance with the Food and Drug Regulations [1718]). Unfortunately, Health Canada has chosen to only "publish 5-7 SBDs per year for newly licensed Class III and IV devices with novel technology” [19], so information related to dates of submission milestones for the majority of medical devices are not publicly-available. Attempts to acquire additional submission timeline information from the Medical Devices Bureau (MDB) were redirected to request information for each device under the Access to Information Act (https://www.canada.ca/en/health-canada/corporate/contact-us/access-information-privacydivision.html). 


\section{Cureus}

\begin{tabular}{|c|c|c|}
\hline Category & FDA 510(k) & Health Canada MDALL \\
\hline Unique Device/Licence identifiers & $\mathrm{x}$ & $\mathrm{x}$ \\
\hline Device name & $\mathrm{x}$ & $\mathrm{x}$ \\
\hline Device classification & $\mathrm{x}$ & $\mathrm{x}$ \\
\hline Manufacturer information & $\mathrm{x}$ & $\mathrm{x}$ \\
\hline Licence issue date & $\mathrm{x}$ & $\mathrm{x}$ \\
\hline Application received date & $\mathrm{x}$ & \\
\hline Manufacturer contact & $\mathrm{x}$ & \\
\hline Relevant Federal Regulations number & $\mathrm{x}$ & \\
\hline Review panel information & $\mathrm{x}$ & \\
\hline PDF summary of decision & $\mathrm{x}$ & \\
\hline Unique company identifier & & X \\
\hline
\end{tabular}

\section{TABLE 4: Summary of Equivalent Outputs of the FDA's 510(k) Premarket Notification}

Database (left) and Health Canada's Medical Devices Active Licence Listing (MDALL)

FDA, food and drug administration

It is important to discuss the limitations of the research presented here. First, to ensure that comparisons between licensing dates were made as accurately as possible, only RODs with exact matches of the device name, version, and applicant/company of manufacture between Health Canada's and the FDA's database were included. However, adherence to this strict inclusion criteria resulted in the exclusion of a number of devices with subtle differences in search criteria. Second, as discussed above, we chose to base the analysis on publicly-available information, and therefore could not perform the intended analysis examining the length of time for the approval process at Health Canada vs. the FDA of the United States. Finally, this research was limited only to North America because of a lack of publicly-available information for medical devices licensed in Europe. The European Database on Medical Devices, Eudamed (https://ec.europa.eu/growth/sectors/medical-devices/market-surveillance_en), is not publicly accessible and therefore data on European radiation oncology devices was not included [20].

\section{Conclusions}

In summary, we observed that $71 \%$ of radiation oncology devices licensed for sale in both Canada and the United States between 2000 and 2018 were licensed in the United States before Canada, a mean of 506 days sooner. Due to a lack of publicly-available information from Health Canada we were unable to rule out the earlier application as a cause for this discrepancy as opposed to differences in duration of approval processes. This highlights the paucity of publicly available data regarding medical device approvals in Canada which is available in the United States.

\section{Appendices}

Supplementary Table 1 


\section{Cureus}

\begin{tabular}{|c|c|c|c|c|c|c|}
\hline Device name & Classification & Company & $\begin{array}{l}\text { CAN } \\
\text { issue } \\
\text { date }\end{array}$ & $\begin{array}{l}\text { USA } \\
\text { issue } \\
\text { date }\end{array}$ & $\begin{array}{l}\text { Date } \\
\text { difference: } \\
\text { USA before } \\
\text { CAN }\end{array}$ & $\begin{array}{l}\text { Date } \\
\text { difference: } \\
\text { CAN before } \\
\text { USA }\end{array}$ \\
\hline Axxent Radiation Shield Rigid & Accessory & $\begin{array}{l}\text { XOFT, INC., A } \\
\text { SUBSIDIARY OF } \\
\text { ICAD }\end{array}$ & $\begin{array}{l}20- \\
\text { Mar- } \\
12\end{array}$ & $\begin{array}{l}20- \\
\text { Jul-11 }\end{array}$ & 244 & $\mathrm{n} / \mathrm{a}$ \\
\hline Spaceoar System & Accessory & AUGMENIX & $\begin{array}{l}5- \\
\text { Feb- } \\
16\end{array}$ & $\begin{array}{l}25- \\
\text { Jun- } \\
18\end{array}$ & $\mathrm{n} / \mathrm{a}$ & 871 \\
\hline I-seed Model AgX100 & Brachytherapy & $\begin{array}{l}\text { THERAGENICS } \\
\text { CORPORATION }\end{array}$ & $\begin{array}{l}\text { 7-Apr- } \\
11\end{array}$ & $\begin{array}{l}3- \\
\text { Jan- } \\
11\end{array}$ & 94 & $\mathrm{n} / \mathrm{a}$ \\
\hline Axxent Vaginal Applicator Set & Brachytherapy & $\begin{array}{l}\text { XOFT, INC., A } \\
\text { SUBSIDIARY OF } \\
\text { ICAD }\end{array}$ & $\begin{array}{l}6- \\
\text { Feb- } \\
09\end{array}$ & $\begin{array}{l}\text { 9- } \\
\text { May- } \\
08\end{array}$ & 273 & $\mathrm{n} / \mathrm{a}$ \\
\hline $\begin{array}{l}\text { Radioactive Seed Localization } \\
\text { Needle }\end{array}$ & Brachytherapy & ISOAID L.L.C. & $\begin{array}{l}19- \\
\text { Jan- } \\
16\end{array}$ & $\begin{array}{l}5- \\
\text { Dec- } \\
14\end{array}$ & 410 & $\mathrm{n} / \mathrm{a}$ \\
\hline $\begin{array}{l}\text { Advantage I-125 Brachytherapy } \\
\text { Seeds }\end{array}$ & Brachytherapy & ISOAID L.L.C. & $\begin{array}{l}\text { 4- } \\
\text { Dec- } \\
03\end{array}$ & $\begin{array}{l}\text { 7- } \\
\text { Oct- } \\
01\end{array}$ & 788 & $\mathrm{n} / \mathrm{a}$ \\
\hline $\begin{array}{l}\text { Advantage Pd-103 Brachytherapy } \\
\text { Seeds }\end{array}$ & Brachytherapy & ISOAID L.L.C. & $\begin{array}{l}\text { 4- } \\
\text { Dec- } \\
03\end{array}$ & $\begin{array}{l}\text { 8- } \\
\text { Apr- } \\
04\end{array}$ & $\mathrm{n} / \mathrm{a}$ & 126 \\
\hline $\begin{array}{l}\text { Axxent Balloon Applicator Kit } \\
\text { AB2034 }\end{array}$ & Brachytherapy & $\begin{array}{l}\text { XOFT, INC., A } \\
\text { SUBSIDIARY OF } \\
\text { ICAD }\end{array}$ & $\begin{array}{l}\text { 6- } \\
\text { Feb- } \\
09\end{array}$ & $\begin{array}{l}\text { 16- } \\
\text { Jul-09 }\end{array}$ & $\mathrm{n} / \mathrm{a}$ & 160 \\
\hline $\begin{array}{l}\text { Exactrac Patient Positioning } \\
\text { System }\end{array}$ & $\begin{array}{l}\text { Imaging \& } \\
\text { Monitoring } \\
\text { Accessory }\end{array}$ & BRAINLAB AG & $\begin{array}{l}25- \\
\text { Jan- } \\
02\end{array}$ & $\begin{array}{l}\text { 14- } \\
\text { Jul-99 }\end{array}$ & 926 & $\mathrm{n} / \mathrm{a}$ \\
\hline Catalyst & $\begin{array}{l}\text { Imaging \& } \\
\text { Monitoring } \\
\text { Accessory }\end{array}$ & $\begin{array}{l}\text { C-RAD } \\
\text { POSITIONING } \\
\text { AB }\end{array}$ & $\begin{array}{l}17- \\
\text { Feb- } \\
15\end{array}$ & $\begin{array}{l}27- \\
\text { Feb- } \\
12\end{array}$ & 1086 & $\mathrm{n} / \mathrm{a}$ \\
\hline Sentinel, Sp-001 & $\begin{array}{l}\text { Imaging \& } \\
\text { Monitoring } \\
\text { Accessory }\end{array}$ & $\begin{array}{l}\text { C-RAD } \\
\text { POSITIONING } \\
\text { AB }\end{array}$ & $\begin{array}{l}30- \\
\text { Apr- } \\
14\end{array}$ & $\begin{array}{l}30- \\
\text { Mar- } \\
09\end{array}$ & 1857 & $\mathrm{n} / \mathrm{a}$ \\
\hline AlignRT & $\begin{array}{l}\text { Imaging \& } \\
\text { Monitoring } \\
\text { Accessory }\end{array}$ & $\begin{array}{l}\text { VISION RT } \\
\text { LIMITED }\end{array}$ & $\begin{array}{l}8-J u l- \\
15\end{array}$ & $\begin{array}{l}\text { 6- } \\
\text { Jan- } \\
06\end{array}$ & 3470 & $\mathrm{n} / \mathrm{a}$ \\
\hline Mridian Linac System & $\begin{array}{l}\text { Linear } \\
\text { Accelerator }\end{array}$ & $\begin{array}{l}\text { VIEWRAY } \\
\text { INCORPORATED }\end{array}$ & $\begin{array}{l}2- \\
\text { Aug- } \\
17\end{array}$ & $\begin{array}{l}24- \\
\text { Feb- } \\
17\end{array}$ & 159 & $\mathrm{n} / \mathrm{a}$ \\
\hline
\end{tabular}




\section{Cureus}

Oncor Expression Digital Linear

Accelerator

Artiste Mv - Linear Accelerator

Halcyon Medical Linear

Accelerator

Tomotherapy Treatment System

Tomohd

Radixact Treatment Delivery

System

Novalis (Shaped Beam Surgery

System)

Cyberknife Robotic Radiosurgery

System - 1000 Mu/Minute Linear

Accelerator

Brainscan Stereotactic

Radiosurgery System

Leksell Gamma Knife Perfexion

Cyberknife M6 Series System

Cyberknife Vsi Robotic

Radiosurgery System

Mevion S250 Proton Beam

Radiation Therapy System
Linear

Accelerator

SIEMENS

Linear

Accelerator

SIEMENS

Linear

Accelerator

VARIAN

MEDICAL

SYSTEMS, INC

Linear

Accelerator

ACCURAY

Linear

Accelerator

ACCURAY

Linear

Accelerator

Linear

Accelerator

ACCURAY

Linear

Accelerator

BRAINLAB AG

Linear

Accelerator

ELEKTA

INSTRUMENT

$\mathrm{AB}$

VARIAN

Linear

Accelerator

MEDICAL

SYSTEMS, INC

Linear

Accelerator

ACCURAY

Linear

Accelerator

ACCURAY

MEVION

Proton

Accelerator
28- 15-

Aug- Mar- 166

$06 \quad 06$

12- 27-

Aug- Dec- 229

$\mathrm{n} / \mathrm{a}$

$08 \quad 07$

27-

Jun- $374 \quad$ n/a

17

27- 29-

Nov- Aug- 455

$\mathrm{n} / \mathrm{a}$

$13 \quad 12$

24

17 Jun- 465

$\mathrm{n} / \mathrm{a}$

16

2- 3-

Dec- Nov- 1124

$\mathrm{n} / \mathrm{a}$

$03 \quad 00$

16- 30-

Aug- Oct- n/a

$06 \quad 06$

8-

Feb- $\quad \begin{array}{ll}13- \\ \text { Jul-00 }\end{array}$

00

30- 5-

Aug- Mar- n/a

$06 \quad 07$

2- 18-

Dec- Aug- n/a

$10 \quad 11$

23- 7-

Oct- Jan- n/a

$13 \quad 15$

18- 26-

Mar- Oct- n/a

$11 \quad 12$

9-Jan- 4-

15 Jun- 949

$\mathrm{n} / \mathrm{a}$ n/a

a




\section{Cureus}

\begin{tabular}{|c|c|c|c|c|c|c|}
\hline Delta4 Phantom+ & Quality Assurance & SCANDIDOS AB & $\begin{array}{l}18- \\
\text { Sep- } \\
15\end{array}$ & $\begin{array}{l}19- \\
\text { Aug- } \\
15\end{array}$ & 30 & $\mathrm{n} / \mathrm{a}$ \\
\hline Perfraction & Quality Assurance & $\begin{array}{l}\text { SUN NUCLEAR } \\
\text { CORPORATION }\end{array}$ & $\begin{array}{l}3-\text { Nov- } \\
14\end{array}$ & $\begin{array}{l}26- \\
\text { Sep- } \\
14\end{array}$ & 38 & $\mathrm{n} / \mathrm{a}$ \\
\hline $\begin{array}{l}\text { Portable Dosimeter } \\
\text { TN-RD-90 }\end{array}$ & Quality Assurance & $\begin{array}{l}\text { BEST MEDICAL } \\
\text { CANADA }\end{array}$ & $\begin{array}{l}25- \\
\text { Oct-10 }\end{array}$ & $\begin{array}{l}28- \\
\text { Aug- } \\
09\end{array}$ & 423 & $\mathrm{n} / \mathrm{a}$ \\
\hline Profiler 2 & Quality Assurance & $\begin{array}{l}\text { SUN NUCLEAR } \\
\text { CORPORATION }\end{array}$ & $\begin{array}{l}\text { 7-Feb- } \\
08\end{array}$ & $\begin{array}{l}22- \\
\text { Nov- } \\
06\end{array}$ & 442 & $\mathrm{n} / \mathrm{a}$ \\
\hline 3D Scanner & Quality Assurance & $\begin{array}{l}\text { SUN NUCLEAR } \\
\text { CORPORATION }\end{array}$ & $\begin{array}{l}29- \\
\text { Sep- } \\
10\end{array}$ & $\begin{array}{l}1-\text { Oct- } \\
10\end{array}$ & $\mathrm{n} / \mathrm{a}$ & 2 \\
\hline $\begin{array}{l}\text { IGM Integral Quality } \\
\text { Monitor }\end{array}$ & Quality Assurance & IRT SYSTEMS GMBH & $\begin{array}{l}14- \\
\text { Sep- } \\
16\end{array}$ & $\begin{array}{l}20- \\
\text { Oct-16 }\end{array}$ & $\mathrm{n} / \mathrm{a}$ & 36 \\
\hline Mobius3d & Quality Assurance & $\begin{array}{l}\text { MOBIUS MEDICAL } \\
\text { SYSTEMS, LP }\end{array}$ & $\begin{array}{l}17- \\
\text { Jan-13 }\end{array}$ & $\begin{array}{l}\text { 24- } \\
\text { Jun-14 }\end{array}$ & $\mathrm{n} / \mathrm{a}$ & 523 \\
\hline $\begin{array}{l}\text { Srt-100 Superficial } \\
\text { Radiation Therapy } \\
\text { System }\end{array}$ & $\begin{array}{l}\text { Superficial } \\
\text { Radiotherapy }\end{array}$ & $\begin{array}{l}\text { SENSUS } \\
\text { HEALTHCARE }\end{array}$ & $\begin{array}{l}1-\text { Nov- } \\
12\end{array}$ & $\begin{array}{l}14- \\
\text { May- } \\
13\end{array}$ & $\mathrm{n} / \mathrm{a}$ & 194 \\
\hline Integrity & $\begin{array}{l}\text { Treatment } \\
\text { Planning/Record \& } \\
\text { Verify Software }\end{array}$ & ELEKTA LIMITED & $\begin{array}{l}27- \\
\text { Jan-12 }\end{array}$ & $\begin{array}{l}16- \\
\text { Dec- } \\
11\end{array}$ & 42 & $\mathrm{n} / \mathrm{a}$ \\
\hline $\begin{array}{l}\text { Aria Radiation } \\
\text { Therapy } \\
\text { Management }\end{array}$ & $\begin{array}{l}\text { Treatment } \\
\text { Planning/Record \& } \\
\text { Verify Software }\end{array}$ & $\begin{array}{l}\text { VARIAN MEDICAL } \\
\text { SYSTEMS, INC }\end{array}$ & $\begin{array}{l}21- \\
\text { May- } \\
14\end{array}$ & $\begin{array}{l}4-A p r- \\
14\end{array}$ & 47 & $\mathrm{n} / \mathrm{a}$ \\
\hline $\begin{array}{l}\text { Iplan! (Stereotactic } \\
\text { Planning Software) }\end{array}$ & $\begin{array}{l}\text { Treatment } \\
\text { Planning/Record \& } \\
\text { Verify Software }\end{array}$ & BRAINLAB AG & $\begin{array}{l}\text { 8-Dec- } \\
04\end{array}$ & $\begin{array}{l}22- \\
\text { Oct-04 }\end{array}$ & 47 & $\mathrm{n} / \mathrm{a}$ \\
\hline Mobile Mim & $\begin{array}{l}\text { Treatment } \\
\text { Planning/Record \& } \\
\text { Verify Software }\end{array}$ & MIM SOFTWARE INC & $\begin{array}{l}24- \\
\text { Mar- } \\
11\end{array}$ & $\begin{array}{l}4-F e b- \\
11\end{array}$ & 48 & $\mathrm{n} / \mathrm{a}$ \\
\hline $\begin{array}{l}\text { Accuray Precision } \\
\text { Treatment Planning } \\
\text { System }\end{array}$ & $\begin{array}{l}\text { Treatment } \\
\text { Planning/Record \& } \\
\text { Verify Software }\end{array}$ & ACCURAY & $\begin{array}{l}30- \\
\text { Oct-17 }\end{array}$ & $\begin{array}{l}8-J u n- \\
17\end{array}$ & 144 & $\mathrm{n} / \mathrm{a}$ \\
\hline iViewDose & $\begin{array}{l}\text { Treatment } \\
\text { Planning/Record \& } \\
\text { Verify Software }\end{array}$ & ELEKTA LIMITED & $\begin{array}{l}27- \\
\text { May- } \\
16\end{array}$ & $\begin{array}{l}11- \\
\text { Dec- } \\
15\end{array}$ & 168 & $\mathrm{n} / \mathrm{a}$ \\
\hline $\begin{array}{l}\text { Eclipse Treatment } \\
\text { Planning System }\end{array}$ & $\begin{array}{l}\text { Treatment } \\
\text { Planning/Record \& }\end{array}$ & $\begin{array}{l}\text { VARIAN MEDICAL } \\
\text { SYSTEMS, INC }\end{array}$ & $\begin{array}{l}\text { 4-Sep- } \\
14\end{array}$ & $\begin{array}{l}\text { 7-Feb- } \\
14\end{array}$ & 209 & $\mathrm{n} / \mathrm{a}$ \\
\hline
\end{tabular}




\section{Cureus}

\begin{tabular}{|c|c|c|c|c|c|c|}
\hline V13.0 & Verify Software & & & & & \\
\hline Raystation 5 & $\begin{array}{l}\text { Treatment } \\
\text { Planning/Record \& } \\
\text { Verify Software }\end{array}$ & $\begin{array}{l}\text { RAYSEARCH } \\
\text { LABORATORIES AB } \\
\text { (PUBL) }\end{array}$ & $\begin{array}{l}14- \\
\text { Nov- } \\
16\end{array}$ & $\begin{array}{l}8-M a r- \\
16\end{array}$ & 251 & $\mathrm{n} / \mathrm{a}$ \\
\hline Variseed 9.0 & $\begin{array}{l}\text { Treatment } \\
\text { Planning/Record \& } \\
\text { Verify Software }\end{array}$ & $\begin{array}{l}\text { VARIAN MEDICAL } \\
\text { SYSTEMS, INC }\end{array}$ & $\begin{array}{l}1-F e b- \\
16\end{array}$ & $\begin{array}{l}8- \\
\text { May- } \\
15\end{array}$ & 269 & $\mathrm{n} / \mathrm{a}$ \\
\hline OnQ rts Software & $\begin{array}{l}\text { Treatment } \\
\text { Planning/Record \& } \\
\text { Verify Software }\end{array}$ & $\begin{array}{l}\text { ONCOLOGY } \\
\text { SYSTEMS LIMITED }\end{array}$ & $\begin{array}{l}27- \\
\text { Sep- } \\
13\end{array}$ & $\begin{array}{l}28- \\
\text { Dec- } \\
12\end{array}$ & 273 & $\mathrm{n} / \mathrm{a}$ \\
\hline $\begin{array}{l}\text { mobileMOSFET } \\
\text { Wireless Dosimetry } \\
\text { System }\end{array}$ & $\begin{array}{l}\text { Treatment } \\
\text { Planning/Record \& } \\
\text { Verify Software }\end{array}$ & $\begin{array}{l}\text { BEST MEDICAL } \\
\text { CANADA }\end{array}$ & $\begin{array}{l}\text { 13- } \\
\text { Apr-05 }\end{array}$ & $\begin{array}{l}\text { 25- } \\
\text { Jun-04 }\end{array}$ & 292 & $\mathrm{n} / \mathrm{a}$ \\
\hline $\begin{array}{l}\text { Eclipse Treatment } \\
\text { Planning System } \\
\text { V15.5 }\end{array}$ & $\begin{array}{l}\text { Treatment } \\
\text { Planning/Record \& } \\
\text { Verify Software }\end{array}$ & $\begin{array}{l}\text { VARIAN MEDICAL } \\
\text { SYSTEMS, INC }\end{array}$ & $\begin{array}{l}6-J u l- \\
18\end{array}$ & $\begin{array}{l}15- \\
\text { Aug- } \\
17\end{array}$ & 325 & $\mathrm{n} / \mathrm{a}$ \\
\hline $\begin{array}{l}\text { Eclipse Treatment } \\
\text { Planning System } \\
\text { V13.5 }\end{array}$ & $\begin{array}{l}\text { Treatment } \\
\text { Planning/Record \& } \\
\text { Verify Software }\end{array}$ & $\begin{array}{l}\text { VARIAN MEDICAL } \\
\text { SYSTEMS, INC }\end{array}$ & $\begin{array}{l}28- \\
\text { Aug- } \\
15\end{array}$ & $\begin{array}{l}7-A u g- \\
14\end{array}$ & 386 & $\mathrm{n} / \mathrm{a}$ \\
\hline Variseed 7.0 & $\begin{array}{l}\text { Treatment } \\
\text { Planning/Record \& } \\
\text { Verify Software }\end{array}$ & $\begin{array}{l}\text { VARIAN MEDICAL } \\
\text { SYSTEMS, INC }\end{array}$ & $\begin{array}{l}31- \\
\text { Jan-03 }\end{array}$ & $\begin{array}{l}\text { 12-Jul- } \\
01\end{array}$ & 568 & $\mathrm{n} / \mathrm{a}$ \\
\hline $\begin{array}{l}\text { Eclipse Treatment } \\
\text { Planning System } \\
\text { V6.5 }\end{array}$ & $\begin{array}{l}\text { Treatment } \\
\text { Planning/Record \& } \\
\text { Verify Software }\end{array}$ & $\begin{array}{l}\text { VARIAN MEDICAL } \\
\text { SYSTEMS, INC }\end{array}$ & $\begin{array}{l}\text { 7-Jun- } \\
04\end{array}$ & $\begin{array}{l}2- \\
\text { May- } \\
01\end{array}$ & 1132 & $\mathrm{n} / \mathrm{a}$ \\
\hline Variseed 7.1 & $\begin{array}{l}\text { Treatment } \\
\text { Planning/Record \& } \\
\text { Verify Software }\end{array}$ & $\begin{array}{l}\text { VARIAN MEDICAL } \\
\text { SYSTEMS, INC }\end{array}$ & $\begin{array}{l}11- \\
\text { Feb- } \\
04\end{array}$ & $\begin{array}{l}21- \\
\text { May- } \\
04\end{array}$ & $\mathrm{n} / \mathrm{a}$ & 100 \\
\hline $\begin{array}{l}\text { Pinnacle } 3 \text { Radiation } \\
\text { Therapy Planning } \\
\text { System }\end{array}$ & $\begin{array}{l}\text { Treatment } \\
\text { Planning/Record \& } \\
\text { Verify Software }\end{array}$ & $\begin{array}{l}\text { PHILIPS MEDICAL } \\
\text { SYSTEMS } \\
\text { (CLEVELAND), INC }\end{array}$ & $\begin{array}{l}28- \\
\text { Feb- } \\
00\end{array}$ & $\begin{array}{l}\text { 14- } \\
\text { Jun-13 }\end{array}$ & $\mathrm{n} / \mathrm{a}$ & 855 \\
\hline
\end{tabular}

\section{TABLE 5: Radiation Oncology Device Listing and Licensure Date for All Categories}

Supplementary Table 2

\begin{tabular}{|c|c|c|c|c|c|}
\hline Number & Device name & Classification & Company & $\begin{array}{l}\text { Canada } \\
\text { issue } \\
\text { date }\end{array}$ & $\begin{array}{l}\text { USA } \\
\text { received } \\
\text { date }\end{array}$ \\
\hline 1 & ABC MOUTHPIECE AND FILTER KIT & ACCESSORY & $\begin{array}{l}\text { AKTINA } \\
\text { MEDICAL }\end{array}$ & $\begin{array}{l}\text { 01-Jun- } \\
18\end{array}$ & $\mathrm{n} / \mathrm{a}$ \\
\hline
\end{tabular}




\section{Cureus}

4 ACTIVE BREATHING CO-ORDINATOR SYSTEM

$6 \quad$ AGILITY

9

10

11

12

13

14

LOGICIEL EPIGRAY

STEREOTACTIC COLLIMATOR

MOBIUS VERIFICATION PHANTOM

DELTA4 DISCOVER

QED

ISORAD

RF IVD2

EDGE DETECTOR

SNC125C (OSMS)

AXXENT SURFACE APPLICATOR SET

IODINE 125 SEEDS

IRIDIUM 192 IN NYLON RIBBONS

PALLADIUM 103

GOLD 198

BRACHYTHERAPY NEEDLES - NON
BARD BRACHYSTAR SEED IMPLANT NEEDLE ACCESSORY

OPTICAL SURFACE MONITORING SYSTEM STAINLESS STEEL

\begin{tabular}{|c|c|c|c|}
\hline ACCESSORY & DOSISOFT & $\begin{array}{l}\text { 02-Feb- } \\
16\end{array}$ & $\mathrm{n} / \mathrm{a}$ \\
\hline ACCESSORY & $\begin{array}{l}\text { ELEKTA } \\
\text { LIMITED }\end{array}$ & $\begin{array}{l}\text { 22-Jul- } \\
05\end{array}$ & $\mathrm{n} / \mathrm{a}$ \\
\hline ACCESSORY & $\begin{array}{l}\text { ELEKTA } \\
\text { LIMITED }\end{array}$ & $\begin{array}{l}21-J u l- \\
09\end{array}$ & $\mathrm{n} / \mathrm{a}$ \\
\hline ACCESSORY & $\begin{array}{l}\text { ELEKTA } \\
\text { LIMITED }\end{array}$ & $\begin{array}{l}15-\text { Nov- } \\
12\end{array}$ & $\mathrm{n} / \mathrm{a}$ \\
\hline ACCESSORY & $\begin{array}{l}\text { MOBIUS } \\
\text { MEDICAL } \\
\text { SYSTEMS, LP }\end{array}$ & $\begin{array}{l}29-A p r- \\
15\end{array}$ & $\mathrm{n} / \mathrm{a}$ \\
\hline ACCESSORY & SCANDIDOS AB & $\begin{array}{l}\text { 07-Feb- } \\
18\end{array}$ & $\mathrm{n} / \mathrm{a}$ \\
\hline ACCESSORY & $\begin{array}{l}\text { SUN NUCLEAR } \\
\text { CORPORATION }\end{array}$ & $\begin{array}{l}\text { 10-Jan- } \\
08\end{array}$ & $\mathrm{n} / \mathrm{a}$ \\
\hline ACCESSORY & $\begin{array}{l}\text { SUN NUCLEAR } \\
\text { CORPORATION }\end{array}$ & $\begin{array}{l}\text { 10-Jan- } \\
08\end{array}$ & $\mathrm{n} / \mathrm{a}$ \\
\hline ACCESSORY & $\begin{array}{l}\text { SUN NUCLEAR } \\
\text { CORPORATION }\end{array}$ & $\begin{array}{l}\text { 16-Jan- } \\
08\end{array}$ & $\mathrm{n} / \mathrm{a}$ \\
\hline ACCESSORY & $\begin{array}{l}\text { SUN NUCLEAR } \\
\text { CORPORATION }\end{array}$ & $\begin{array}{l}\text { 07-Feb- } \\
08\end{array}$ & $\mathrm{n} / \mathrm{a}$ \\
\hline ACCESSORY & $\begin{array}{l}\text { SUN NUCLEAR } \\
\text { CORPORATION }\end{array}$ & $\begin{array}{l}\text { 09-Nov- } \\
11\end{array}$ & $\mathrm{n} / \mathrm{a}$ \\
\hline ACCESSORY & $\begin{array}{l}\text { VISION RT } \\
\text { LIMITED }\end{array}$ & $\begin{array}{l}\text { 29-Jul- } \\
16\end{array}$ & $\mathrm{n} / \mathrm{a}$ \\
\hline ACCESSORY & $\begin{array}{l}\text { XOFT, INC., A } \\
\text { SUBSIDIARY OF } \\
\text { ICAD }\end{array}$ & $\begin{array}{l}\text { 07-Oct- } \\
10\end{array}$ & $\mathrm{n} / \mathrm{a}$ \\
\hline BRACHYTHERAPY & $\begin{array}{l}\text { BEST MEDICAL } \\
\text { INTERNATIONAL }\end{array}$ & $\begin{array}{l}\text { 26-Jun- } \\
01\end{array}$ & $\mathrm{n} / \mathrm{a}$ \\
\hline BRACHYTHERAPY & $\begin{array}{l}\text { BEST MEDICAL } \\
\text { INTERNATIONAL }\end{array}$ & $\begin{array}{l}\text { 26-Jun- } \\
01\end{array}$ & $\mathrm{n} / \mathrm{a}$ \\
\hline BRACHYTHERAPY & $\begin{array}{l}\text { BEST MEDICAL } \\
\text { INTERNATIONAL }\end{array}$ & $\begin{array}{l}\text { 26-Jun- } \\
01\end{array}$ & $\mathrm{n} / \mathrm{a}$ \\
\hline BRACHYTHERAPY & $\begin{array}{l}\text { BEST MEDICAL } \\
\text { INTERNATIONAL }\end{array}$ & $\begin{array}{l}\text { 26-Jun- } \\
01\end{array}$ & $\mathrm{n} / \mathrm{a}$ \\
\hline BRACHYTHERAPY & $\begin{array}{l}\text { BEST MEDICAL } \\
\text { INTERNATIONAL }\end{array}$ & $\begin{array}{l}\text { 10-Sep- } \\
01\end{array}$ & \\
\hline
\end{tabular}




\section{Cureus}

BRACHYTHERAPY NEEDLES - STAINLESS STEEL

BRACHYTHERAPY IMPLANT/APPLICATOR KITS

BRACHYTHERAPY MARKER KITS

STYLETS FOR BRACHYTHERAPY NEEDLES

PD-103 SOURCES PRELOADED

I-125 SOURCES PRELOADED

POLYACETAL BRACHYTHERAPY KITS

BRACHYTHERAPY STANDARD TEMPLATES

BRACHYTHERAPY DISPOSABLE TEMPLATE KITS

BEST MULTI-LUMEN BALLOON APPLICATOR FOR BRACHYTHERAPY

ANORECTAL (AR) APPLICATOR

ESOPHAGEAL APPLICATOR (E-APP)

BRACHYTHERAPY KIT

GUIDE FOR BRACHYTHERAPY NEEDLE

ISOLOADER SYSTEM

ISOCARTRIDGE

BRACHYTHERAPY NEEDLE

BRACHYTHERAPY SYNTHETIC ABSORBABLE, BRAIDED AND NON BRAIDED PLACEMENT SLEEVES

BRACHYTHERAPY NEEDLES
BRACHYTHERAPY BEST MEDICAL 10-Sep- n/a INTERNATIONAL 01

BRACHYTHERAPY

BEST MEDICAL 10-SepINTERNATIONAL 01

BRACHYTHERAPY BEST MEDICAL 26-Sep- n/a INTERNATIONAL 01

BEST MEDICAL 31INTERNATIONAL May-06 n/a

BRACHYTHERAPY

BEST MEDICAL 26-JulINTERNATIONAL 06 n/a

BRACHYTHERAPY

BEST MEDICAL 26-Jul- n/a INTERNATIONAL 06

BEST MEDICAL 08-Oct- n/a INTERNATIONAL 09

BEST MEDICAL 21-Feb- n/a INTERNATIONAL 12

BEST MEDICAL 21-Feb- n/a INTERNATIONAL 12

BEST MEDICAL 09-Dec- n/a INTERNATIONAL 14

BIONIX

BRACHYTHERAPY

RADIATION

04-Aug17

THERAPY

BIONIX

BRACHYTHERAPY

RADIATION

04-Aug17 $n / a$ THERAPY

BRACHYTHERAPY

ISOAID L.L.C.

03-Jun11

18-Jun- n/a

BRACHYTHERAPY

ISOAID L.L.C. 13

BRACHYTHERAPY CORPORATION

27-Nov01

BRACHYTHERAPY

THERAGENICS

22-AprCORPORATION 02

BRACHYTHERAPY CORPORATION $02 \quad$ n/a

BRACHYTHERAPY THERAGENICS 06-FebCORPORATION 03 $\mathrm{n} / \mathrm{a}$

THERAGENICS 18-JunCORPORATION 03 


\section{Cureus}

46

47

48

49

50

51

52

53

54

55

56

57

58
BRACHYTHERAPY NEEDLE SETS

GOLD FIDUCIARY MARKERS

BRACHYTHERAPY APPLICATOR KITS

PROSTATE SEEDING KITS (THERALOAD,

THERASEED, THERASTRAND,

THERASLEEVE)

THERASEED PD-103 DEVICE

AXXENT ELECTRONIC BRACHYTHERAPY SYSTEM

$\mathrm{MLCl} 2$

ELEKTA MEDICAL LINEAR ACCELERATOR

CHECKMATE 2

DAILY QA 3

DAILY QA 3 RF

TOMODOSE

SRS PROFILER

MAPCHECK 2

IC PROFILER

PC ELECTROMETER

ARCCHECK

3DVH ANALYSIS SOFTWARE

1D SCANNER
BRACHYTHERAPY CORPORATION

18-Dec03 $\mathrm{n} / \mathrm{a}$

BRACHYTHERAPY

THERAGENICS 30-JanCORPORATION 09

BRACHYTHERAPY

THERAGENICS 09-JulCORPORATION 10

$\mathrm{n} / \mathrm{a}$

BRACHYTHERAPY

THERAGENICS CORPORATION

25-Jan11

XOFT, INC., A

BRACHYTHERAPY SUBSIDIARY OF ICAD

06-Feb- n/a

ELEKTA

LIMITED

03-Apr-

09

ELEKTA

LIMITED

26-Aug- n/a 10

SUN NUCLEAR 16-JanCORPORATION 08

SUN NUCLEAR 16-Jan- n/a CORPORATION 08

SUN NUCLEAR 16-Jan- n/a CORPORATION 08

SUN NUCLEAR 07-Feb- n/a CORPORATION 08

SUN NUCLEAR 31-DecCORPORATION 08

SUN NUCLEAR 31-Dec- n/a CORPORATION 08

SUN NUCLEAR 24-FebCORPORATION $09 \quad \mathrm{n} / \mathrm{a}$

SUN NUCLEAR 08-JunCORPORATION $09 \quad \mathrm{n} / \mathrm{a}$

SUN NUCLEAR 19-Aug- n/a CORPORATION 09

SUN NUCLEAR 16-JunCORPORATION 10

SUN NUCLEAR 11-AprCORPORATION 11 


\section{Cureus}

\begin{tabular}{|c|c|c|c|c|c|}
\hline 59 & STEREOPHAN & QA & $\begin{array}{l}\text { SUN NUCLEAR } \\
\text { CORPORATION }\end{array}$ & $\begin{array}{l}16-J u l- \\
13\end{array}$ & $\mathrm{n} / \mathrm{a}$ \\
\hline 60 & SNC MACHINE & QA & $\begin{array}{l}\text { SUN NUCLEAR } \\
\text { CORPORATION }\end{array}$ & $\begin{array}{l}15- \\
\text { May-15 }\end{array}$ & $\mathrm{n} / \mathrm{a}$ \\
\hline 61 & DOSECHECK & QA & $\begin{array}{l}\text { SUN NUCLEAR } \\
\text { CORPORATION }\end{array}$ & $\begin{array}{l}\text { 19- } \\
\text { May-16 }\end{array}$ & $\mathrm{n} / \mathrm{a}$ \\
\hline 62 & MAPCHECK 3 & QA & $\begin{array}{l}\text { SUN NUCLEAR } \\
\text { CORPORATION }\end{array}$ & $\begin{array}{l}\text { 19-Sep- } \\
17\end{array}$ & $\mathrm{n} / \mathrm{a}$ \\
\hline 63 & SUNCHECK & QA & $\begin{array}{l}\text { SUN NUCLEAR } \\
\text { CORPORATION }\end{array}$ & $\begin{array}{l}18-D e c- \\
17\end{array}$ & $\mathrm{n} / \mathrm{a}$ \\
\hline 64 & SRS MAPCHECK & QA & $\begin{array}{l}\text { SUN NUCLEAR } \\
\text { CORPORATION }\end{array}$ & $\begin{array}{l}\text { 31- } \\
\text { May-18 }\end{array}$ & $\mathrm{n} / \mathrm{a}$ \\
\hline 65 & $\begin{array}{l}\text { RADIATION QUALITY ASSURANCE } \\
\text { SOFTWARE (DOSELAB) }\end{array}$ & SOFTWARE & $\begin{array}{l}\text { MOBIUS } \\
\text { MEDICAL } \\
\text { SYSTEMS, LP }\end{array}$ & $\begin{array}{l}\text { 26-Mar- } \\
11\end{array}$ & $\mathrm{n} / \mathrm{a}$ \\
\hline 66 & $\begin{array}{l}\text { SRT-100 VISION SUPERFICIAL RADIATION } \\
\text { THERAPY SYSTEM }\end{array}$ & SUPERFICIAL RT & $\begin{array}{l}\text { SENSUS } \\
\text { HEALTHCARE }\end{array}$ & $\begin{array}{l}\text { 30-Mar- } \\
16\end{array}$ & $\mathrm{n} / \mathrm{a}$ \\
\hline 67 & $\begin{array}{l}\text { RADPOS 4-D IN-VIVO DOSIMETRY SYSTEM } \\
\text { TN-RD-140 }\end{array}$ & $\begin{array}{l}\text { TREATMENT } \\
\text { PLANNING }\end{array}$ & $\begin{array}{l}\text { BEST MEDICAL } \\
\text { CANADA }\end{array}$ & $\begin{array}{l}30-\text { Dec- } \\
10\end{array}$ & $\mathrm{n} / \mathrm{a}$ \\
\hline 68 & MIM (SOFTWARE PACKAGE) & $\begin{array}{l}\text { TREATMENT } \\
\text { PLANNING }\end{array}$ & $\begin{array}{l}\text { MIM SOFTWARE } \\
\text { INC }\end{array}$ & $\begin{array}{l}\text { 03-Oct- } \\
05\end{array}$ & $\mathrm{n} / \mathrm{a}$ \\
\hline 69 & MIMVIEWER & $\begin{array}{l}\text { TREATMENT } \\
\text { PLANNING }\end{array}$ & $\begin{array}{l}\text { MIM SOFTWARE } \\
\text { INC }\end{array}$ & $\begin{array}{l}\text { 05-Jan- } \\
09\end{array}$ & $\mathrm{n} / \mathrm{a}$ \\
\hline 70 & $\begin{array}{l}\text { RIT } 113 \text { RADIATION THERAPY DOSIMETRY } \\
\text { SOFTWARE }\end{array}$ & $\begin{array}{l}\text { TREATMENT } \\
\text { PLANNING }\end{array}$ & $\begin{array}{l}\text { RADIOLOGICAL } \\
\text { IMAGING } \\
\text { TECHNOLOGY }\end{array}$ & $\begin{array}{l}\text { 26-Apr- } \\
06\end{array}$ & $\mathrm{n} / \mathrm{a}$ \\
\hline 71 & INVERSEARC 1.0 & $\begin{array}{l}\text { TREATMENT } \\
\text { PLANNING }\end{array}$ & $\begin{array}{l}\text { RAYSEARCH } \\
\text { LABORATORIES } \\
\text { AB (PUBL) }\end{array}$ & $\begin{array}{l}\text { 01-Jun- } \\
15\end{array}$ & $\mathrm{n} / \mathrm{a}$ \\
\hline 72 & DELTA 4PT & $\begin{array}{l}\text { TREATMENT } \\
\text { PLANNING }\end{array}$ & SCANDIDOS AB & $\begin{array}{l}\text { 26-Mar- } \\
13\end{array}$ & $\mathrm{n} / \mathrm{a}$ \\
\hline 73 & HEXAMOTION & $\begin{array}{l}\text { TREATMENT } \\
\text { PLANNING }\end{array}$ & SCANDIDOS AB & $\begin{array}{l}\text { 21-Jan- } \\
14\end{array}$ & $\mathrm{n} / \mathrm{a}$ \\
\hline 74 & PLANIQ & $\begin{array}{l}\text { TREATMENT } \\
\text { PLANNING }\end{array}$ & $\begin{array}{l}\text { SUN NUCLEAR } \\
\text { CORPORATION }\end{array}$ & $\begin{array}{l}\text { 23-Mar- } \\
15\end{array}$ & \\
\hline
\end{tabular}

\section{TABLE 6: Excluded Devices}




\section{Disclosures}

Human subjects: All authors have confirmed that this study did not involve human participants or tissue. Animal subjects: All authors have confirmed that this study did not involve animal subjects or tissue. Conflicts of interest: In compliance with the ICMJE uniform disclosure form, all authors declare the following: Payment/services info: All authors have declared that no financial support was received from any organization for the submitted work. Financial relationships: All authors have declared that they have no financial relationships at present or within the previous three years with any organizations that might have an interest in the submitted work. Other relationships: All authors have declared that there are no other relationships or activities that could appear to have influenced the submitted work.

\section{References}

1. Connor MJ, Tringale K, Moiseenko V, et al.: Medical device recalls in radiation oncology: analysis of US Food and Drug Administration data, 2002-2015. Int J Radiat Oncol Biol Phys. 2017, 98:438446. 10.1016/j.ijrobp.2017.02.006

2. Ross S, Weijer C, Gafni A, Ducey A, Thompson C, Lafreniere R: Ethics, economics and the regulation and adoption of new medical devices: case studies in pelvic floor surgery. BMC Med Ethics. 2010, 11:14. 10.1186/1472-6939-11-14

3. Therapeutic products directorate. (2019). Accessed: March 27, 2019: https://www.canada.ca/en/health-canada/corporate/about-health-canada/branchesagencies/health-products-food-branch/th....

4. Class II nuclear facilities and prescribed equipment. (2019). Accessed: March 27, 2019: http://nuclearsafety.gc.ca/eng/nuclear-substances/licensing-class-II-nuclear-facilities-andprescribed-equipment/inde....

5. Chen YJ, Chiou CM, Huang YW, Tu PW, Lee YC, Chien CH: A comparative study of medical device regulations: US, Europe, Canada, and Taiwan. Ther Innov Regul Sci. 2018, 52:62-69. $10.1177 / 2168479017716712$

6. Laws and regulations (radiation-emitting products). (2018). Accessed: September 4, 2018: https://www.fda.gov/Radiation-

EmittingProducts/ElectronicProductRadiationControlProgram/LawsandRegulations/ucm2007155..

7. Getting a radiation emitting product to market . (2018). Accessed: September 4, 2018: https://www.fda.gov/Radiation-

EmittingProducts/ElectronicProductRadiationControlProgram/LawsandRegulations/ucm2007155..

8. Ezeife DA, Truong TH, Heng DY, Bourque S, Welch SA, Tang PA: Comparison of oncology drug approval between Health Canada and the US Food and Drug Administration. Cancer. 2015, 121:1688-1693. 10.1002/cncr.29246

9. Downing NS, Aminawung JA, Shah ND, Braunstein JB, Krumholz HM, Ross JS: Regulatory review of novel therapeutics--comparison of three regulatory agencies. N Engl J Med. 2012, 366:22842293. 10.1056/NEJMsa1200223

10. Bristow RE, Chang J, Ziogas A, Campos B, Chavez LR, Anton-Culver H: Impact of National Cancer Institute Comprehensive Cancer Centers on ovarian cancer treatment and survival. J Am Coll Surg. 2015, 220:940-950. 10.1016/j.jamcollsurg.2015.01.056

11. The medical technology industry in the United States . (2018). Accessed: September 10, 2018: https://www.selectusa.gov/medical-technology-industry-united-states .

12. Industry profile. (2017). Accessed: September 11, 2018: https://www.ic.gc.ca/eic/site/lsgpdsv.nsf/eng/h_hn01736.html.

13. Guidance on medical device establishment licensing and medical device establishment licence fees. (2017). Accessed: September 19, 2018: https://www.canada.ca/en/healthcanada/services/drugs-health-products/compliance-enforcement/establishment-licences/d....

14. Medical device licence application review. (2018). Accessed: September 19, 2018: https://www.canada.ca/en/health-canada/services/drugs-health-products/funding-fees/feesrespect-human-drugs-medical-d....

15. Right to sell licensed class II, III, or IV medical devices . (2018). Accessed: September 19, 2018 : https://www.canada.ca/en/health-canada/services/drugs-health-products/funding-fees/feesrespect-human-drugs-medical-d....

16. FY 2019 MDUFA user fees. (2018). Accessed: September 19, 2018: https://www.fda.gov/ForIndustry/UserFees/MedicalDeviceUserFee/ucm615142.htm.. 


\section{Cureus}

17. Notice of compliance (NOC) database (2017). Accessed: September 5, 2018:

https://www.canada.ca/en/health-canada/services/drugs-health-products/drug-products/noticecompliance/database.html.

18. Summary basis of decision (SBD). (2018). Accessed: September 11, 2018:

https://www.canada.ca/en/health-canada/services/drugs-health-products/drugproducts/summary-basis-decision.html.

19. Frequently asked questions: summary basis of decision (SBD) project: phase II . (2018). Accessed: September 11, 2018: https://www.canada.ca/en/health-canada/services/drugs-healthproducts/drug-products/summary-basis-decision/frequently....

20. Market surveillance and vigilance. (2018). Accessed: September 12, 2018:

https://ec.europa.eu/growth/sectors/medical-devices/current-directives/market-surveillance_en. 